\title{
The impact of globalization in connection with the development of e-commerce
}

\author{
Eva Nahalková Tesárová1,*, Anna Križanová ${ }^{1}$ \\ ${ }^{1}$ University of Zilina, Faculty of Operation and Economics of Transport and Communications, \\ Univerzitna 1, 01026 Zilina, Slovakia
}

\begin{abstract}
Research background: Globalization encourages increased involvement of retailers, and the market currently provides these entities with a new range of purchasing functions. The new economy is based primarily on information and knowledge, so the key to success is the ability to constantly improve and respond to changing market conditions and increasing customer requirements. The Internet thus becomes an integral part of our lives. It is a tool that makes our lives better. The expansion of the global information network Internet has created space for a new kind of business. It brings benefits to all e-commerce entities. For this reason, its popularity is growing exponentially. The negative experience caused by financial fraud, misuse of sensitive data, the unreliability of business partners, and the like is also growing.

Purpose of the article: The basic purpose of the article is the fact that the development of e-commerce is one of the important conditions for maintaining and increasing the competitiveness of the Slovak economy and its ability to participate in the international division of labor with the economically developed countries.

Methods: The basic pillar of the article was to analyze the current development of e-commerce in the Slovak Republic, which is affected by the pandemic situation caused by COVID-19, make a comparison with EU countries, and evaluate the perception of e-commerce by Slovak consumers based on a questionnaire survey.

Findings \& Value added: Finally, we interpret the answers of the respondents, which were obtained by the questionnaire method.
\end{abstract}

Keywords: globalization; e-commerce; Slovak consumers

JEL Classification: $M 31 ; F 60 ; L 81$

${ }^{*}$ Corresponding author: eva.tesarova@ 


\section{Introduction}

The new economy is based primarily on information and knowledge, so the key to success is the ability to constantly improve and respond to changing market conditions and increasing customer requirements. The Internet thus becomes an integral part of our lives. It is a tool that makes our lives better. The expansion of the global information network Internet has created space for a new kind of business. It brings benefits to all e-commerce entities. For this reason, its popularity is growing exponentially. The negative experience caused by financial fraud, misuse of sensitive data, unreliability of business partners and the like is also growing. The development of electronic commerce is one of the important conditions for maintaining and increasing the competitiveness of the Slovak economy (Dvorský et al. 2020) and its ability to participate in the international division of labor with economically developed countries. E-commerce has a great impact on future trade relations, on the creation and implementation of trade policy in the domestic and international framework.

\subsection{Literature review}

Globalization has created a new global economy that provides companies with opportunities to access new markets and participate in global production networks (Aydin \& Savrul, 2014). As a result of globalization and market openness, economic and distribution conditions as well as promotional conditions are changing, resulting in strong competition and increasingly demanding conditions for the consumption (Gajanová et al., 2020; Klieštiková et al., 2017; Gajanova et al., 2021) and sale of products and services (Bulanda et al., 2020). Globalization and technological change have created a new global economy "driven by technology, driven by" information "and driven by" knowledge " (Totonchi \& Kakamanshadi., 2011). According to Held \& McGrew (2000) term ,globalization“ " is a conceptualization of the international political economy and is currently one of the most controversial and discussed topics in general. Totonchi \& Kakamanshadi (2011) and others deals with the diffusion of ecommerce into the business environment, its global advantages and disadvantages. The approach of the domestic, national and international economy is called globalization. Leads to increased challenge and competition related to costs and prices of products and services, target market, technological variations, rapid customer response at the international level (Ituarte et al., 2016). Globalization is a broader concept that is based on connecting the world in more sophisticated ways by increasing mutual relations. It has opened up traditional and local markets around the world to increase trade and foster relationships through common business interests. Globalization is linked to the revolution of the last decade of the 20th century, which massively facilitated this cause (Jahan et al., 2021). Sparke (2013) defined the term by saying that globalization is in fact a combination of concepts to promote social, political and economic connectivity between countries. He noted that this phenomenon has a series of positive and negative effects on businesses. He also claimed that this had changed the dynamics of the business and the market. Ted Brink (2013) pointed out that economic connections between countries are the most relevant for companies that aim to open markets to international players and help them make money around the world. He further argued that the influences of companies are not limited to economic interests, but that political and cultural differences also have a significant impact on companies. Companies invest in information technology and e-commerce in order to increase the efficiency of operations and improve customer service. The research of Civelek et al. (2020) points to the use of social media in countries such as Slovakia, the Czech Republic and Hungary. They found that small and medium-sized enterprises in Hungary use online marketing (Nadanyiova \& Kramarova, 2013 ) to a greater extent. False content on social networks was studied by Popescu \& Olah (2020) and Sheares et al. (2020). Several infrastructures form the basic basis for the spread 
of e-commerce. Among them, the most important are telecommunications, information technology, the Internet, financial resources and delivery systems (Tan \& Quyang, 2003). According to Dvoŕák, e-commerce is the provision of the company's business activities through a variety of information and communication technologies. Another definition says that e-commerce can be understood as the exchange of information through an electronic medium in order to close a trade or to support it. We call business processes that we carry out electronically using information technologies and information systems electronic business (Chromý, 2013). Electronic business (e-business) is the broadest area of business activities carried out on the Internet, and it also includes electronic commerce (e-commerce). We can therefore understand e-business as the use of electronic platforms - intranet, extranet and internet for the implementation of business by the company (Kotler et al., 2004). It is therefore not only the purchase and sale of goods and services, but also the provision of services to customers, cooperation with business partners, the implementation of transactions between organizations or the provision of e-learning (Turban et. al, 2018). Kalakota and Winston (1997) consider e-commerce to be all electronically mediated exchanges of information between an organization and its interest groups, stakeholders, which include a communication perspective, business processes, services, and an online perspective. Jason et al. (2000) argue in their paper that the rapid development of e-commerce causes various problems for companies. However, companies are pushing for their e-commerce strategies, with some concerns that if they do not have e-commerce strategies, they will lose customers over competitors. The implementation of e-commerce principles in business relationships of any level depends on many factors. The most important factors are the overall state of the country's economy; the situation on the world market; economic status of the main partners; level of state regulation of foreign economic activity. To characterize these factors and assess their impact on the country's integration processes in the international e-commerce system, it is important to select an appropriate set of indicators. One of the models was created in a publication by Babenko et al. (2019).

\section{Methods}

The basic pillar of the article is the analysis of the concepts of globalization and e-commerce, followed by the generalization of these concepts and mutual causality. In this paper we will further analyze the current development of e-commerce worldwide, using data on the platform Statista, which is affected by the pandemic situation caused by COVID-19, compare the e-commerce of the Slovak Republic with EU countries and evaluate the perception of ecommerce by Slovak consumers based on a questionnaire survey. The survey was conducted at the beginning of 2020 and the number of respondents was 511.

\section{Results}

With the advent of e-commerce, we have seen their annual growth, which continues. As can be seen in Chart 1, e-commerce sales are on an upward trend. Significant growth in ecommerce occurred in 2020 as a result of measures against the COVID-19 pandemic, when consumer shopping behavior changed and e-shop sales recorded record growth. The increase in e-commerce revenue was mainly due to measures taken by national governments around the world, when in-store stores remained closed to prevent population mobility and thus eliminate the spread of COVID-19. 


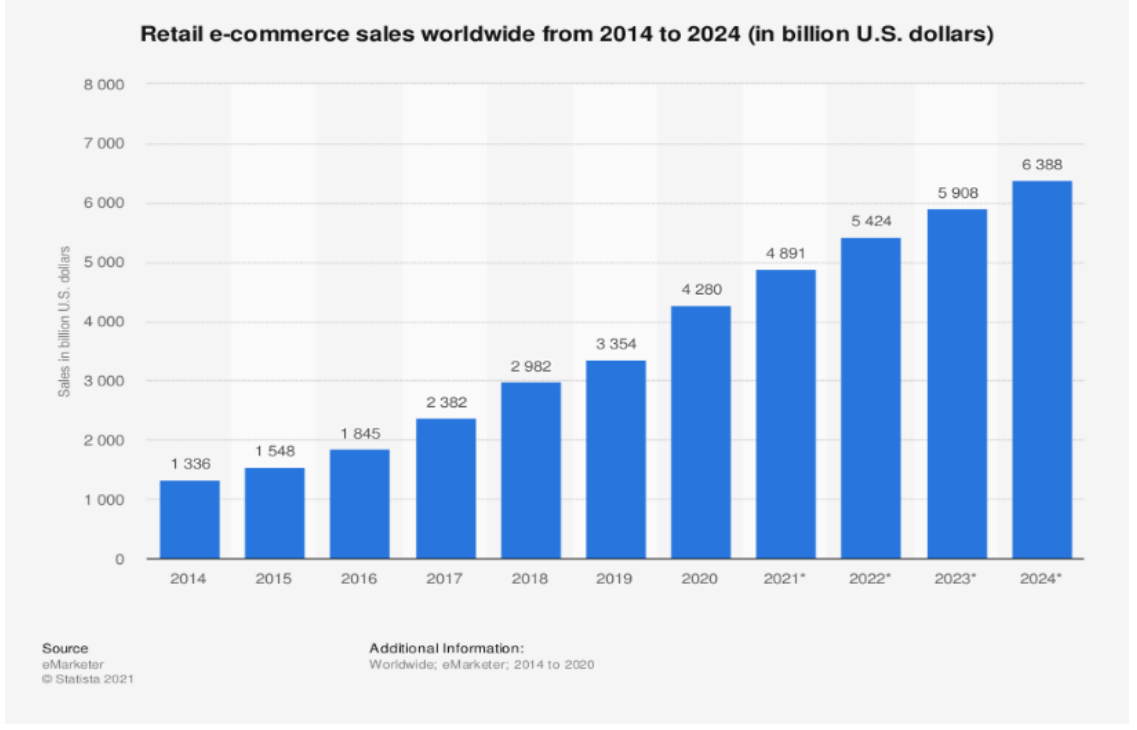

Figure 1. Development of e-commerce

Source: https://www.statista.com/

According to statista.com, the e-retail sector accounted for $13.6 \%$ of all retail transactions in 2019 worldwide. In 2020, e-commerce retail sales worldwide reached \$ 4.28 trillion, and forecasts suggest that revenue from e-retail will grow to $\$ 6.38$ trillion in 2024 , and the overall share of e-commerce in global retail sales will be $3.8 \%$ higher than in 2020 . The sphere of ecommerce continues to grow steadily despite some economic uncertainty caused by the coronavirus pandemic. This is an interesting phenomenon as total retail sales have declined. Although e-commerce makes up only a relatively small part of the retail "pie", its dynamics is much higher.

Online shopping in the European Union continues to grow. With regard to physical shopping affected by COVID-19 restrictions and changes in habits and preferences, further growth in e-commerce can be expected. Accorting paltform In 2019, 89\% of people aged 1674 in the EU used the internet, $72 \%$ of whom bought or ordered goods or services for private purposes. Online shopping increased by 4 percentage points compared to 2019 (68\% of internet users) and by 10 percentage points compared to 2015 (62\%). In 2019, more than 8 out of 10 Internet users in the Netherlands (91\%), Denmark (90\%), Germany (87\%), Sweden $(86 \%)$ and Ireland $(81 \%)$ bought or ordered goods or services via the Internet. On the other hand, less than 50\% shopped online in Bulgaria (42\%), Romania (45\%) and Italy (49\%). 


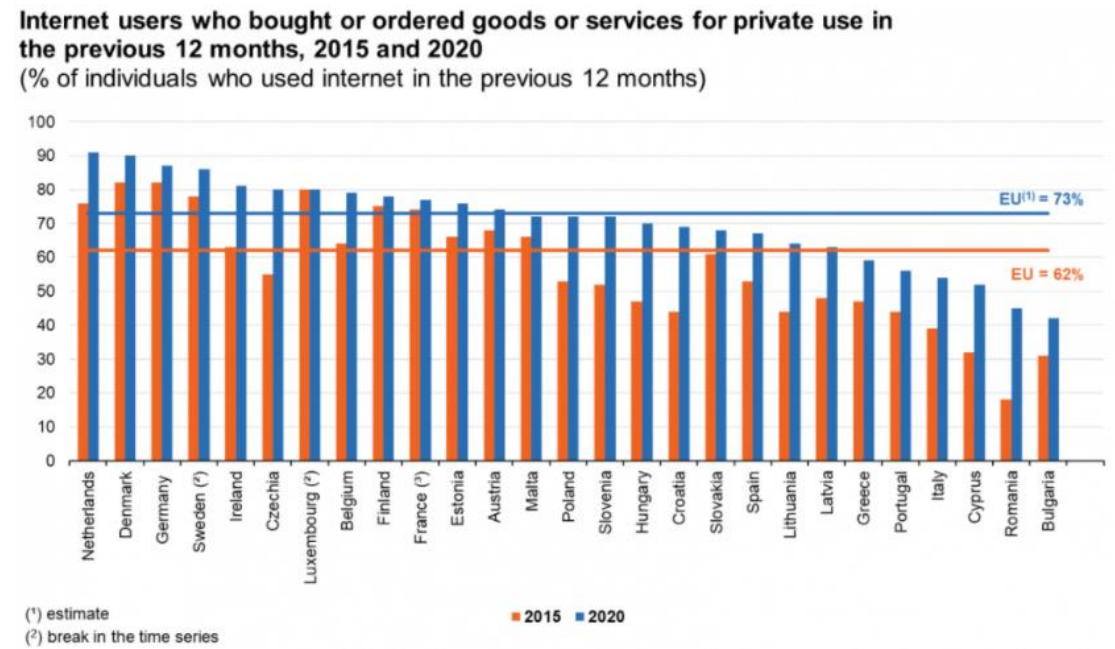

Figure 2. Development of e-commerce in EU

Source: https://ec.europa.eu/eurostat

\section{Perception of e-commerce by Slovak consumers}

As part of the researched issue, we conducted a questionnaire survey, which included respondents. We used a questionnaire to find out the perception of e-commerce by Slovak consumers. The structure of respondents by gender was represented by almost $73.14 \%$ of the female population. Men made up $26.86 \%$ of respondents. According to generational stratification, the largest part was Generation $\mathrm{Z}$ and zoomers, respectively, $62.75 \%$, followed by Generation Y, milenials with a share of $27.84 \%$, Generation X was represented by $5.88 \%$ and the smallest share is represented by respondents of the baby boomers group. Respondents who came from the city accounted for $57.84 \%$. From the countryside it was $42.16 \%$. From the economic point of view, the respondents were divided into 6 groups as follows: employed (26.47\%), student (61.18\%), domestic (3.92\%), entrepreneur (3.73\%), unemployed $(3,13 \%)$ and a pensioner $(1.57 \%)$. Out of 511 respondents, only $2.94 \%$ did not make purchases via the Internet, of which 8 were men and 7 women. They were mostly members of the generation of baby boomers living in the city who were retired. When asked how often Slovak consumers make their purchase, $1.76 \%$ of respondents/daily, $48.04 \% /$ month, $9.80 \% /$ halfyear, $25.49 \%$ /quarter, $12.94 \%$ /week answered and did not make an electronic purchase at all $1,96 \%$ of respondents. In the questionnaire, we also assessed the importance of selected ecommerce factors and answered the questions as follows: the most important aspect is considered the most important aspect of the seller's credibility of up to $66.34 \%$ (339); price $53.03 \%$ (271); customer reviews 50.68\% (259); detailed description of goods 50,10\% (256); delivery rate $49.51 \%$ (253); personal data protection $45.99 \%$ (235); ease of searching for goods $42.47 \%$ (217), ordering goods outside opening hours $36.20 \%$ (185); assortment width $36.01 \%$ (184). Less important was the appearance of the website with a share of $31.70 \%$ (162). The neutral attitude of the respondents to the aspect was the possibility of comparing several products $29.16 \%$ (149) and the promotion of goods $39.73 \%$ (203).

\section{Discussion}

Digitization intensified by the COVID-19 pandemic presents great opportunities for economic growth and business development. At the same time, it brings challenges such as new demands on human capabilities (Malkawi \& Khayrullina, 2021 ; Foster et al. 2020 ; 
Vetrakova et al., 2018). A number of authors worldwide have addressed the topic of consumer perception of e-commerce. The authors Gburová \& Fedorko (2018), who carried out a questionnaire survey within one region (Prešov), focused on e-commerce in Slovakia as consumers perceive e-commerce. The most common products that Slovaks buy on the Internet are: clothes and shoes (35.5\%), electronics (25.8\%), books, CDs and DVDs (12.8\%), cosmetics $(9.7 \%)$ and a trip or vacation $(8.4 \%)$. Corbitt et al. (2003) found in their research that people shop more often from the web if they perceive a higher degree of trust in ecommerce and have more experience using the web. The level of customer confidence is likely to be affected by the level of perceived market orientation, site quality, technical credibility, and user experience with the site. In their study, Yoon \& Occeña (2015) examined trust in $\mathrm{C} 2 \mathrm{C}$ e-commerce, where they found that trust in $\mathrm{C} 2 \mathrm{C}$ e-commerce can be mitigated by age. Research (Van Slyke et al., 2005) conducted using the diffusion of innovation theory and the literature on the credibility of e-commerce and the dimensions of national culture as theoretical starting points examines how consumers perceive e-commerce in India and the US. The results suggest that Indian and American consumers perceive the relative advantage, ease of use, compatibility and provability of e-commerce results differently.

\section{Conclusion}

E-commerce is a common part of life today. People are increasingly using this form of trading, which is easier, more convenient and in some cases cheaper for many. So far, the biggest disadvantage seems to be the unavailability of the Internet for all residents in terms of price and availability. However, the development of information technology is still progressive and it is only a matter of time before more and more people use the Internet and all the benefits it brings. The future of e-commerce should be for the benefit of online customers, whether through offerings, availability or ease of ordering.

\section{Acknowledgement}

The article is the output of the VEGA project no. 1/0032/21: Marketing engineering as a progressive platform for optimizing managerial decision-making processes in the context of the current challenges of marketing management.

\section{References}

1. Aydın, E., \& Savrul, B. K. (2014). The relationship between globalization and ecommerce: Turkish case. Procedia-Social and Behavioral Sciences, 150, 1267-1276.

2. Babenko, V., Kulczyk, Z., Perevosova, I., Syniavska, O., \& Davydova, O. (2019). Factors of the development of international e-commerce under the conditions of globalization. SHS Web of Conferences, 65, 04016.

3. Bulanda, I., Kádeková, Z, Košičiarová, I., \& Vavrečka, V. (2020). The perception of commercial and social advertising by the generation $\mathrm{Y}$ in the Czech Republic, Ekonomicko-manazerske spektrum, 14(2), 63-77.

4. CHROMÝ, J. (2013) Elektronické Podnikání: Informace, Komunikace, Přiležitosti. Praha: Extrasystém.

5. Civelek, M., Gajdka, K., Světlík, J., \& Vavrečka, V. (2020). Differences in the usage of online marketing and social media tools: evidence from Czech, Slovakian and Hungarian smes. Equilibrium. Quarterly Journal of Economics and Economic Policy, 15(3), 537563. 
6. Corbitt, B. J., Thanasankit, T., \& Yi, H. (2003). Trust And E-Commerce: A Study Of Consumer Perceptions. Electronic Commerce Research And Applications, 2(3), $203-$ 215.

7. Dvořák, J. A, \& Dvořák, J. (2004). Elektronický Obchod. Brno : Vut v Brně.

8. Dvorský, J., Petráková, Z., Ajaz Khan, K., Formánek, I., \& Mikoláš, Z. (2020). Selected Aspects Of Strategic Management In The Service Sector. Journal Of Tourism And Services, 20(11), 109-123.

9. Gajanova, L., Nadanyiova, M., \& Lazaroiu, G. (2020). Specifics In Brand Value Sources Of Customers In The Banking Industry From The Psychographic Point Of View. Central European Business Review, 9(2), 1-18

10. Gburova, J., \& Fedorko, R. (2018). Online Shops And Online Shopping From The Point Of View Of The Slovak Consumer. Economic And Social Development: Book Of Proceedings, 134-140.

11. Held, D., \& Mcgrew, A. (2000). The Global Transformations Reader (Vol. 13). Cambridge: Polity Press.

12. Ituarte, I. F., Khajavi, S. H., \& Partanen, J. (2016). Challenges To Implementing Additive Manufacturing In Globalised Production Environments. International Journal Of Collaborative Enterprise, 5(3-4), 232-247.

13. Jahan, S., Alrajawy, I., Ali, S. A., \& Martin, P. (2021). Analysing The Impact Of Globalisation On Business Performance: Case Of Uae Food Industry. International Journal For Quality Research, 15(2), 665-678.

14. Jason, H., Frank, D., \& Jay, A. (2000). Adoption Of E-Commerce Strategies For Agribusiness Firms. In Selected Paper At The American Agriculture Economics Association Annual Meeting. Tampa FL. $1-25$.

15. Kalakota, R., \& Whinston, A. B. (1997). Electronic Commerce: A Manager's Guide. Addison-Wesley Professional.

16. Kliestikova, J., Janoskova, K. (2017). Branding With Understanding: How National Profile Of Consumer Influences Brand Value Perception. Marketing And Management Of Innovations, 3, 149-157.

17. Kotler, P., Armstrong, G.(2004). Marketing. Praha: Grada Publishing.

18. Nadanyiova, M., \& Kramarova, K. (2013). Marketing and its impacts on consumers' green purchasing behaviour. Marketing Identity, 423-435.

19. Foster, B., Saputra, J., \& Grabowska, M. (2020). Communication Strategy Planning in Influencing the Intention to Visit: An Implication to Marketing Management. Polish Journal of Management Studies, 22(1), 117-133.

20. Kolarov, K., \& Georgieva, S. (2020). Management Features in Bulgarian Smes as Determinants of Business Internationalization. Polish Journal of Management Studies, 22(1), 279-294.

21. Gajanova, L., Nadanyiova, M., Majerova, J., \& Aljarah, A. (2021). Brand value sources in banking industry: Evidence for marketing communication across generational cohorts. Polish Journal of Management Studies, 23(1), 151-171.

22. Vetrakova, M., Hitka, M., Potkany, M., Lorincova, S., Smerek, L. (2018). Corporate Sustainability in the Process of Employee Recruitment through Social Networks in Conditions of Slovak Small and Medium Enterprises. Sustainability, 10(5), 1670.

23. Malkawi, E., Khayrullina, M. (2021). Digital Human Skills From The Corporate Economy And Business Development. Ekonomicko-Manazerske Spektrum, 15(1), 6474. 
24. Popescu L. D., \& Olah, M. L. (2020). Regulating Fake News Content during COVID19 Pandemic: Evidence-based Reality, Trustworthy Sources, and Responsible Media Reporting. Review of Contemporary Philosophy, 19, 43-49.

25. Sheares, G., Miklencicova, R., \& Grupac, M. (2020). The Viral Power of Fake News: Subjective Social Insecurity, COVID-19 Damaging Misinformation, and Baseless Conspiracy Theories. Linguistic and Philosophical Investigations, 19, 121-127.

26. Sparke, M. (2013). Introducing globalisation: Ties, tensions, and uneven integration. 1 -25 . John Wiley \& Sons.

27. Tan, Z. A., \& Ouyang, W. (2003). Globalization and e-commerce I: Factors affecting ecommerce diffusion in China. Communications of the Association for Information Systems, 10(1), 2.

28. Ten Brink, T. (2013). Paradoxes of prosperity in China's new capitalism. Journal of Current Chinese Affairs, 42(4), 17-44.

29. Totonchi, J., \& Kakamanshadi, G. (2011). Globalization and e-commerce. In 2nd International Conference on Networking and Information Technology (17), 270-276. IACSIT Press, Singapore.

30. Van Slyke, C., Belanger, F., \& Sridhar, V. (2005). A comparison of American and Indian consumers' perceptions of electronic commerce. Information Resources Management Journal (IRMJ), 18(2), 24-40.

31. Yoon, H. S., \& Occeña, L. G. (2015). Influencing factors of trust in consumer-toconsumer electronic commerce with gender and age. International journal of information management, 35(3), 352-363. 